\title{
STRATEGI PENGELOLAAN TERUMBU KARANG DI KEPULAUAN SERIBU
}

\author{
Strategic of Coral Reef Management in the Kepulauan Seribu
}

\author{
Nyoman Darma Adi ${ }^{\mathrm{a}}$, Ario Damar ${ }^{\mathrm{b}, \mathrm{c}}$, Luky Adrianto ${ }^{\mathrm{b}, \mathrm{c}}$, Dedi Sudarma ${ }^{\mathrm{d}}$ dan Akhmad Solihin ${ }^{\mathrm{c}, \mathrm{e}}$ \\ a Program Studi Ilmu Pengelolaan Daerah Aliran Sungai, Sekolah Pascasarjana, Institut Pertanian Bogor, Kampus \\ IPB Dramaga, Bogor 16680 —adidarma42@gmail.com \\ ${ }^{b}$ Departemen Manajemen Sumberdaya Perairan, Institut Pertanian Bogor, Kampus IPB Darmaga, Bogor 16680 \\ ${ }^{c}$ Pusat Kajian Sumberdaya Pesisir dan Lautan (PKSPL-IPB), Kampus IPB Baranang Siang \\ ${ }^{d}$ Departemen Ilmu dan Teknologi Kelautan, , Institut Pertanian Bogor, Kampus IPB Darmaga, Bogor 16680 \\ ${ }^{e}$ Departemen Pemanfaatan Sumberdaya Perikanan, Institut Pertanian Bogor, Kampus IPB Darmaga, Bogor 16680
}

\begin{abstract}
The aims of this research is to analyse the issues and prolems in coral reef management in order to established the strategy to achieve sustainable coral reef management. The study done during period of July to November 2015 in the Kepulauan Seribu district, DKI Jakarta. Reseach method was descriptive with case study. Data gathering using the triangulation method. Furthermore, data analysis using AWOT (Analythical Hierarchy Procedure and Strenght-Weakness-Opportunity-Threath) which is the combination of SWOT and Analytical Hierarchy Process (AHP) technique. The results showed that the problems of coral reef management was different in North and South area and therfore, the strategy applied in two different area is different. Moreover, the best strategy for North area was located in $1^{\text {st }}$. quadrant (strategi Strength-Opportunity where for South area the strategy located at $2^{\text {nd }}$ quadrant (strategi Strength-Treath).Based on this results, the best program to be applied at South area is Community based solid waste management while for North area is implement the Co-Management
\end{abstract}

Keywords: AHP, AWOT, kepulauan Seribu, SWOT, terumbu karang.

(Diterima: 02-09-2017; Disetujui: 05-12-2017)

\section{Pendahuluan}

Ekosistem terumbu karang memiliki kelengkapan struktur tropik yang tinggi seperti habitat bagi berbagai jenis ikan, biota moluska dan echinodermata. Hal ini sebagaimana disebutkan dalam Cesar et al., (1997) yang diacu Bengen dan Retraubun (2006), bahwa manfaat yang terkandung dalam terumbu karang dikelompokkan menjadi dua, yaitu: manfaat langsung dan manfaat tidak langsung. Manfaat langsung adalah bahan baku bangunan dan industri, sebagai penghasil beragam sumberdaya ikan, dan manfaat tidak langsungnya adalah fungsi terumbu karang sebagai penahan abrasi pantai, peredam gelombang, dan sumber keanekaragaman hayati.

Berdasarkan hasil analisis citra ALOS tahun 2008 untuk lokasi Kepulauan Seribu komposisi karang hidup mencapai $68.53 \%$ dari $1.873,4$ ha total area luasan ekosistem terumbu karang (Suku Dinas Kelautan dan Pertanian Provinsi DKI Jakarta, 2009). Keberlanjutan ekosistem terumbu karang merupakan jaminan bagi keberlanjutan kegiatan perikanan tangkap dan wisata di kawasan Kepulauan Seribu, sehingga perlu dilakukan kajian strategi pengelolaan terumbu karang untuk mendukung usaha perikanan tangkap dan wisata bahari.

Keberlanjutan ekosistem terumbu karang mengalami ancaman akibat bom ikan dan potassium dalam rentang waktu 2006-2010 di sekitar perairan Karang Congkak, yang diakibatkan kesalahan persepsi refor- masi dan lemahnya penegakan hukum (Santoso, 2010). Praktik-praktik nelayan tradisional juga berpengaruh sebagaimana terjadi Pulau Siompu, Kabupaten Buton (Haruddin et al., 2011). Selain itu, adalah gangguan antropogenik seperti polusi, limbah cair dan sampah, serta tingginya aktivitas lalu-lintas pelayaran sebagaimana yang terjadi di sekitar perairan Pulau Tidung (Widiarti dan Ramadhan, 2015). Gangguan tersebut semakin berpengaruh, ketika lokasi terumbu karang semakin dekat dengan daratan utama (Ruswahyuni dan Pujiono, 2009). Pada tahun 2011 tutupan karang di zona inti Taman Nasional mengalami penurunan sebesar $4,54 \%$ dalam 2 tahun, di zona pemukiman mengalami kenaikan sebesar $0,19 \%$ selama 2 tahun. Sedangkan di zona pariwisata mengalami penurunan sebesar $8,07 \%$ dan di zona perlindungan mengalami penurunan sebesar $7,79 \%$ (Faizal dan Iriana, 2012).

Penelitian yang dilakukan oleh Cleary et al. (2014) menemukan bahwa terumbu karang mengalami penurunan antara tahun 1985-1995, kemudian mengalami pemulihan kembali pada tahun 2005-2011 (Cleary et al., 2014)

Tujuan penelitian ini yaitu memetakan isu permasalahan keberadaan ekosistem terumbu karang di Kepulauan Seribu dan menyusun strategi pengelolaan dalam mewujudkan terumbu karang berkelanjutan. 


\section{Metode}

\subsection{Waktu dan Tempat Penelitian}

Penelitian ini dilaksanakan pada bulan Juli dan November 2015 di Kabupaten Administrasi Kepulauan Seribu, DKI Jakarta. Lokasi penelitian dibagi menjadi dua wilayah, yaitu wilayah Utara dan Selatan. Wilayah Selatan di dalam penelitian ini meliputi pulau pulau yang termasuk wilayah Kecamatan Kepulauan Seribu Selatan (P. Pari, P, Tidung Besar, P. Tidung Kecil, P. Tidung Besar, P. Panggan, dan P. Karya sedangkan wilayah Utara adalah pulau-pulau yang termasuk wilayah Kecamatan Kepulauan Seribu Utara (P. Kelapa, P. Harapan, P. Sepa, P. Pantara Barat, P, Pantara Timur).

\subsection{Metode Pengumpulan Data}

Metode yang digunakan dalam penelitian ini yaitu metode deskriptif dengan studi kasus. Metode deskriptif digunakan untuk mengumpulkan data mengenai aktivitas dan kondisi ekosistem terumbu karang di Kepulauan Seribu. Studi kasus digunakan untuk menganalisis strategi pengelolaan yang harus dilakukan dalam mewujudkan keberlanjutan ekosistem terumbu karang.

Sumber data yang digunakan dalam penelitian ini mencakup data primer yang bersifat kualitatif dan data sekunder yang bersifat kuantitatif. Menurut Kusmayadi dan Endar (2000), data primer adalah data yang dikumpulkan dari sumber pertama melalui wawancara, tes, observasi dan lain-lain. Sementara itu, data sekunder adalah data yang dikumpulkan dari laporan tahunan, bahan pustaka atau hasil penelitian orang lain yang berhubungan dengan penelitian ini. Jumlah responden sebanyak 12 orang yang berasal dari berbagai pemangku kepentingan.

Data primer diperoleh melalui pengamatan langsung di lapangan dan wawancara secara mendalam dengan responden, yaitu Pemerintah (Balai Taman Nasional Nasional Kepulauan Seribu dan Suku Dinas Kelautan, Pertanian dan Peternakan DKI Jakarta), perwakilan pengusaha wisata bahari, nelayan dan ketua kelompok pengelola terumbu karang. Menurut Nasir (1988) metode wawancara adalah proses memperoleh ke-terangan untuk tujuan penelitian dengan cara tanya jawab sambil bertatap muka antara si penanya atau pewawancara dengan si penjawab atau informan dengan menggunakan alat yang dinamakan panduan wawancara (interview guide)

Pengumpulan data sebagaimana dipaparkan di atas merupakan metode triangulasi. Menurut Sitorus (1998), triangulasi dapat diartikan sebagai "kombinasi sumber data" yang memadukan sedikitnya tiga metode, seperti pengamatan, wawancara dan analisis dokumen. Kelebihan dari metode ini adalah saling menutupi kelemahan antara satu metode dengan metode lainnya, sehingga hasil yang diharapkan dari realitas sosial masyarakat menjadi lebih valid (Mulyana, 2001).

\subsection{Analisis Data}

Analisis penelitian ini menggunakan AWOT yang menggabungkan analisis SWOT dengan Analytical Hierarchy Process (AHP). Analytical Hierarchy Process merupakan teknik pengambilan keputusan yang pertama kali dikembangkan oleh Thomas L. Saaty. AHP pada dasarnya didesain untuk menangkap secara rasional persepsi orang yang berhubungan erat dengan permasalahan tertentu melalui prosedur yang didesain untuk sampai pada suatu kala preferensi diantara berbagai alternatif (Saaty, 1993). Menurut Kangas et al. (1998) penggunaan pairwise comparison dalam SWOT ini menghasilkan teknik yang disebut sebagai A'WOT atau AHP-SWOT. Cara ini akan menghasilkan perumusan strategi yang terboboti.

Untuk mengidentifikasi faktor-faktor strategis dalam pengelolaan terumbu karang dilakukan analisis SWOT. Strategi kebijakan pengelolaan terumbu karang disusun berdasarkan hasil identifikasi faktor internal dan eksternal. Faktor internal didefinisikan sebagai faktor yang berasal dari dalam lingkungan, yang dalam hal ini adalah sistem pengelolaan, khususnya di Kepulauan Seribu, sedangkan faktor eksternal adalah faktor yang berasal dari luar (Robinson, 1997).

\section{Hasil dan Pembahasan}

\subsection{Wilayah Selatan Kepulauan Seribu}

Isu dan permasalahan terkait dengan unsur kekuatan di wilayah Selatan Kepulauan Seribu, yaitu: (1) kesadaran masyarakat terhadap perikanan berkelanjutan; (2) adanya kelompok pengelola; (3) dukungan pemerintah yang kuat; dan (4) keberadaan regulasi (Peraturan Gubernur/SK). Sementara unsur kelemahannya, yaitu: (1) kualitas terumbu karang buruk; (2) lemahnya koordinasi antar lembaga terkait; (3) kelompok pengelola belum optimal; dan (4) ketergantungan pendanaan pengelolaan dari luar. Unsur peluang, yaitu: (1) adanya dukungan lembaga nonpemerintah dan swasta; (2) pengembangan pemanfaatan ekowisata; dan (3) pengembangan pendidikan lingkungan dan kelautan bagi pelajar, mahasiswa dan masyarakat. Sedangkan unsur ancamannya, yaitu: (1) masih adanya aktivitas masyarakat penambang pasir dan terumbu karang; (2) pencemaran yang bersumber dari sampah dan bahan organik; (3) Kegiatan wisata massal dan belum ramah lingkungan; dan (4) kegiatan perikanan yang merusak.

Berdasarkan hasil analisis pada Tabel 1, maka disusun alternatif strategi dengan menggunakan matriks SWOT, yang merupakan kombinasi dari strategi SO, WO, ST, dan WT. Perumusan strategi dilakukan dengan mempertimbangkan keempat faktor yaitu kekuatan, kelemahan, peluang, dan ancaman yang telah diidentifikasi. Strategi yang dihasilkan merupakan kombinasi SO (strength-opportunities), ST (strengththreats), WO (weakness-opportunities), dan WT (weakness-threats) yang dirangkum dalam matriks 
SWOT. Perumusan strategi pengelolaan terumbu karang yang dibangun dengan menggunakan matriks SWOT dapat dilihat pada Tabel 2.

Berdasarkan Tabel 1 dan Tabel 2 dapat dihitung nilai IFAS yang merupakan selisih total nilai pengaruh faktor internal (kekuatan dan kelemahan) sebesar $1.4063-1.2813=0.1250$, sedangkan nilai EFAS yang merupakan selisih total nilai pengaruh faktor eksternal (peluang dan ancaman) sebesar $0.8477-1.6328=(-$ $0.7852)$. Nilai IFAS positif berarti secara kumulatif faktor kekuatan lebih besar dibandingkan faktor kelemahan, dan nilai EFAS negatif berarti secara kumulatif faktor peluang lebih kecil dari faktor ancaman (Gambar 1).

Tabel 1. Nilai unsur SWOT pengelolaan terumbu karang di Wilayah Selatan Kepulauan Seribu

\begin{tabular}{|c|c|c|c|c|}
\hline No & Unsur SWOT & Bobot & Skala & Skor \\
\hline \multicolumn{5}{|c|}{ Kekuatan } \\
\hline 1 & $\begin{array}{l}\text { Kesadaran masyarakat } \\
\text { terhadap perikanan berke- } \\
\text { lanjutan }\end{array}$ & 0.175 & 3.5 & 0.6125 \\
\hline 2 & $\begin{array}{l}\text { Sudah ada kelompok- } \\
\text { kelompok pengelola }\end{array}$ & 0.1625 & 3.25 & 0.5281 \\
\hline 3 & $\begin{array}{l}\text { Dukungan pemerintah } \\
\text { yang kuat }\end{array}$ & 0.0875 & 1.75 & 0.1531 \\
\hline \multirow[t]{3}{*}{4} & $\begin{array}{l}\text { Keberadaan regulasi (Pera- } \\
\text { turan Gubernur/SK) }\end{array}$ & 0.075 & 1.5 & 0.1125 \\
\hline & Total & & & 1.4063 \\
\hline & Kelemahan & & & \\
\hline 1 & $\begin{array}{l}\text { Lemahnya koordinasi antar } \\
\text { lembaga terkait }\end{array}$ & 0.1000 & 2.00 & 0.2000 \\
\hline 2 & $\begin{array}{l}\text { Kelompok pengelola be- } \\
\text { lum optimal }\end{array}$ & 0.1500 & 3.00 & 0.4500 \\
\hline 3 & $\begin{array}{l}\text { Ketergantungan pendanaan } \\
\text { pengelolaan dari luar }\end{array}$ & 0.1375 & 2.75 & 0.3781 \\
\hline \multirow[t]{3}{*}{4} & $\begin{array}{l}\text { Kualitas terumbu karang } \\
\text { buruk }\end{array}$ & 0.1125 & 2.25 & 0.2531 \\
\hline & Total & & & 1.2813 \\
\hline & Peluang & & & \\
\hline 1 & $\begin{array}{l}\text { Adanya dukungan lembaga } \\
\text { non pemerintah dan private }\end{array}$ & 0.0938 & 1.5 & 0.1406 \\
\hline 2 & $\begin{array}{l}\text { Pengembangan pemanfaa- } \\
\text { tan ekowisata }\end{array}$ & 0.1094 & 1.75 & 0.1914 \\
\hline \multirow[t]{3}{*}{3} & $\begin{array}{l}\text { Pengembangan pendidikan } \\
\text { lingkungan dan kelautan } \\
\text { bagi pelajar, mahasiwa dan } \\
\text { masyarakat }\end{array}$ & 0.1875 & 2.75 & 0.5156 \\
\hline & Total & & & 0.8477 \\
\hline & Ancaman & & & \\
\hline 1 & $\begin{array}{l}\text { Masih adanya aktivitas } \\
\text { masyarakat penambang } \\
\text { pasir dan terumbu karang }\end{array}$ & 0.1563 & 2.5 & 0.3906 \\
\hline 2 & $\begin{array}{l}\text { Pencemaran yang } \text { ber- } \\
\text { sumber dari sampah dan } \\
\text { bahan organik }\end{array}$ & 0.1563 & 2.5 & 0.3906 \\
\hline 3 & $\begin{array}{l}\text { Kegiatan wisata yang } \\
\text { massal dan belum ramah } \\
\text { lingkungan }\end{array}$ & 0.1094 & 1.75 & 0.1914 \\
\hline \multirow[t]{2}{*}{4} & $\begin{array}{l}\text { Kegiatan perikanan yang } \\
\text { merusak }\end{array}$ & 0.2031 & 3.25 & 0.6602 \\
\hline & Total & & & 1.6328 \\
\hline
\end{tabular}

Gambar 1 menunjukkan bahwa pengelolaan terumbu karang berada pada kuadran 2. Artinya, posisi ini menandakan pengelolaan terumbu karang menghadapi tantangan yang besar. Rekomendasi strategi yang diberikan adalah diversifikasi strategi, artinya pengelolaan terumbu karang dalam kondisi mantap namun menghadapi sejumlah tantangan berat sehingga diperkirakan pengelolaan yang efektif akan mengalami kesulitan. Oleh karenanya, pengelolaan terumbu karang disarankan untuk segera memperbanyak ragam strategi taktisnya. Oleh karena itu, strategi yang terpilih, yaitu: Alternatif A (Pengelolaan sampah berbasis masyarakat); Alternatif B (Penguatan kelompok pengelola menjadi kelompok pengawas yang didasarkan aturan lokal); Alternatif C (Pengembangan wisata ramah lingkungan); dan Alternatif D (Pengaturan dan pengalihan alat tangkap merusak).

Tabel 2. Matrik SWOT Untuk Perumusan Kebijakan Terumbu Karang di Wilayah Selatan Kepulauan Seribu

\begin{tabular}{|c|c|c|}
\hline EFAS & $\begin{array}{l}\text { Kekuatan (Strengths) } \\
\text { S1.Kesadaran masyara- } \\
\text { kat terhadap perikanan } \\
\text { berkelanjutan; } \\
\text { S2.Sudah adanya ke- } \\
\text { lompok-kelompok } \\
\text { pengelola; } \\
\text { S3. Dukungan } \\
\text { pemerintah yang kuat } \\
\text { S4. Keberadaan regulasi }\end{array}$ & $\begin{array}{l}\text { Kelemahan (Weak- } \\
\text { nesses) } \\
\text { W1. Lemahnya } \\
\text { koordinasi antar } \\
\text { lembaga terkait; } \\
\text { W2. Kelompok } \\
\text { pengelola belum } \\
\text { optimal; } \\
\text { W3. Ketergantungan } \\
\text { pendanaan pengel- } \\
\text { olaan dari luar } \\
\text { W4. Kualitas terumbu } \\
\text { karang buruk }\end{array}$ \\
\hline $\begin{array}{l}\text { Peluang (Op- } \\
\text { portunities) } \\
\text { O1. Adanya } \\
\text { dukungan lem- } \\
\text { baga non } \\
\text { pemerintah dan } \\
\text { private; } \\
\text { O2. Pengem- } \\
\text { bangan pem- } \\
\text { anfaatan ekow- } \\
\text { isata; } \\
\text { O3. Pengem- } \\
\text { bangan pendidi- } \\
\text { kan lingkungan } \\
\text { dan kelautan } \\
\text { bagi pelajar, } \\
\text { mahasiwa dan } \\
\text { masyarakat }\end{array}$ & $\begin{array}{l}\text { SO } \\
\text { SO1. Membangun Co- } \\
\text { management (S1, S2, } \\
\text { S3, O1, O2) } \\
\text { SO2. Aturan lokal } \\
\text { kegiatan wisata berke- } \\
\text { lanjutan (S1, S2, O2) } \\
\text { SO3. Penguatan kele- } \\
\text { ompok konservasi dalam } \\
\text { kegiatan ekowisata (S1, } \\
\text { S2, S3, O3) }\end{array}$ & $\begin{array}{l}\text { WO } \\
\text { WO1. Membangun } \\
\text { forum stakeholder } \\
(\mathrm{W} 1, \mathrm{~W} 2, \mathrm{O} 1, \mathrm{O} 2) \\
\text { WO 2. Peningkatan } \\
\text { kapasitas lembaga } \\
\text { konservasi (W2, W3, } \\
\text { O1, O2) } \\
\text { WO 3. Trust Fund } \\
\text { konservasi berbasis } \\
\text { wisata (W3, O1, O2) }\end{array}$ \\
\hline $\begin{array}{l}\text { Ancaman } \\
\text { (Threats) } \\
\text { T1. Masih } \\
\text { adanya aktivita } \\
\text { masyarakat } \\
\text { penambang } \\
\text { pasir dan } \\
\text { terumbu karang; } \\
\text { T2. Pencemaran } \\
\text { yang bersumber } \\
\text { dari sampah dan } \\
\text { bahan organik; } \\
\text { T3. Kegiatan } \\
\text { wisata yang } \\
\text { massal dan } \\
\text { belum ramah } \\
\text { lingkungan } \\
\text { T4. Kegiatan } \\
\text { perikanan yang }\end{array}$ & $\begin{array}{l}\text { ST } \\
\text { ST1. Pengelolaan sam- } \\
\text { pah berbasis masyarakat } \\
\text { (S1, S2, S3, T2) } \\
\text { ST2. Penguatan ke- } \\
\text { lompok pengelola men- } \\
\text { jadi kelompok pengawas } \\
\text { yang didasarkan aturan } \\
\text { lokal (S1, S2, S3, T1, } \\
\text { T2,T3) } \\
\text { ST3. Pengembangan } \\
\text { wisata ramah ling- } \\
\text { kungan (S1, S2, S3, T3) } \\
\text { ST4. Pengaturan dan } \\
\text { pengalihan alat tangkap } \\
\text { merusak (S1, S2, S3, } \\
\text { T4) }\end{array}$ & $\begin{array}{l}\text { WT } \\
\text { WT1. Monitoring } \\
\text { bersama (W1, T1, T2, } \\
\text { T3) } \\
\text { WT2. Pelibatan ke- } \\
\text { lompok dalam } \\
\text { pencegahan pencema- } \\
\text { ran (W1, W2, T2) } \\
\text { WT3. Trust Fund } \\
\text { konservasi berbasis } \\
\text { wisata (W3, T1, T2, } \\
\text { T3) } \\
\text { WT4. Pemetaan } \\
\text { kelembagaan wisata } \\
\text { bahari di Kepulauan } \\
\text { Seribu (W2, W3, T1, } \\
\text { T2, T3) }\end{array}$ \\
\hline
\end{tabular}




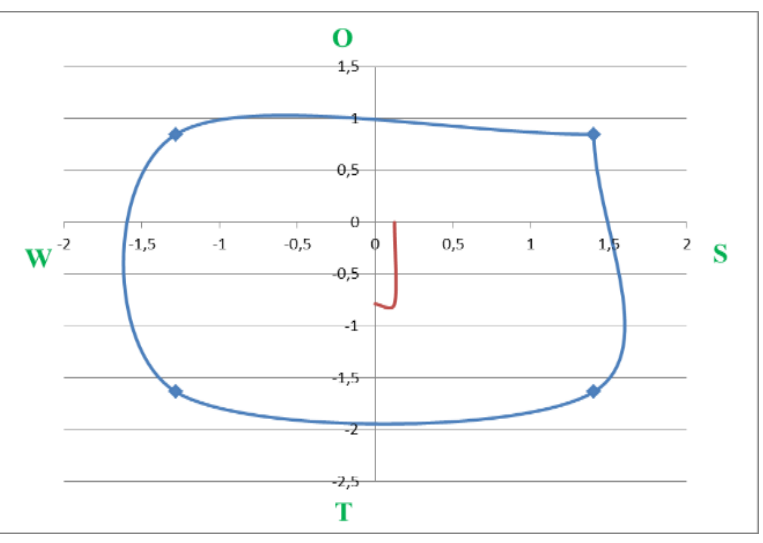

Gambar 1. Diagram matrik space wilayah Selatan Kepulauan Seribu

Langkah analisis selanjutnya adalah menentukan strategi prioritas pengelolaan terumbu karang. Hal ini dikarenakan, tidak mungkin semua alternatif program tersebut dapat diimplementasikan dalam waktu yang bersamaan, karena faktor keterbatasan anggaran dan waktu para pengambil kebijakan. Berdasarkan hasil analisis tersebut dapat dibuat struktur hierarki seperti dapat dilihat pada Gambar 2. Dari struktur hierarki ini diperoleh bobot kepentingan yang menunjukkan prioritas dari empat alternatif strategi dalam pengelolaan terumbu karang.

Dengan menggunakan perangkat lunak expert choice 2000, maka akan didapat nilai rangking prioritas strategi pengelolaan seperti ditampilkan pada Gambar 3. Selain itu dengan menggunakan expert choice akan dihasilkan nilai rasio konsistensi (consistency ratio) (CR) yang menunjukkan apakah kuisioner yang diisi oleh para respondens konsisten atau tidak. Apabila nilai $\mathrm{CR}>0,1$, maka pengisian kuisioner tidak konsisten sehingga perlu dilakukan adjustment atau revisi pendapat.

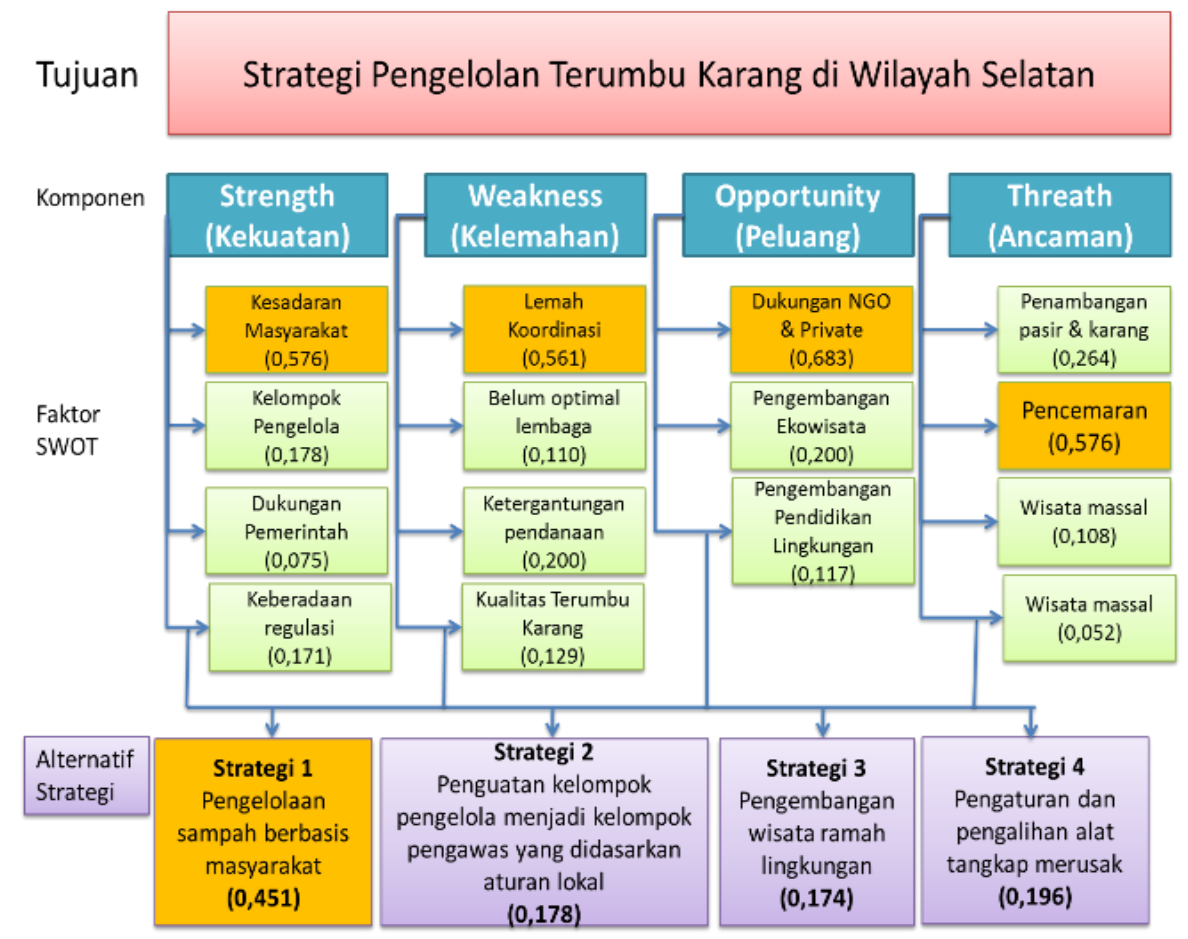

Gambar 2. Struktur hierarki pengembangan pengelolaan terumbu karang di wilayah Selatan Kepulauan Seribu

Berdasarkan struktur hierarki tersebut, strategis prioritas pengelolaan terumbu karang dianalisis dengan menggunakan Expert Choice dan hasilnya ditampilkan pada Gambar 3. Prioritas strategi terpilih adalah pengelolaan sampah berbasis masyarakat dengan nilai $45,1 \%$; prioritas kedua adalah pengaturan dan pengalihan alat tangkap merusak dengan nilai 19,6\%; prioritas ketiga adalah penguatan kelompok pengelola menjadi kelompok pengawas yang didasarkan aturan lokal dengan nilai $17,8 \%$; dan pengembangan wisata ramah lingkungan dengan nilai $17,4 \%$.

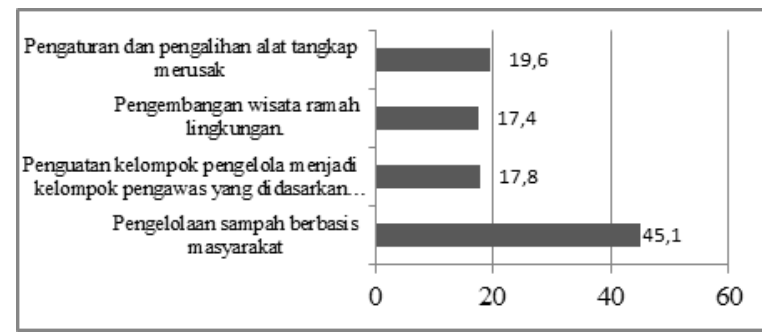

Gambar 3. Strategi prioritas pengelolaan terumbu karang di wilayah Selatan Kepulauan Seribu 


\subsection{Wilayah Utara Kepulauan Seribu}

Isu dan permasalahan terkait dengan unsur kekuatan di wilayah Utara Kepulauan Seribu, yaitu: (1) kesadaran masyarakat terhadap perikanan berkelanjutan; (2) dukungan pemerintah yang kuat; (3) keberadaan regulasi; dan (4) kualitas terumbu karang sedang. Sementara unsur kelemahannya, yaitu: (1) lemahnya koordinasi antar lembaga terkait; (2) kurangnya pembentukan kelompok pengelola; dan (3) pendanaan terbatas. Unsur peluang, yaitu: (1) adanya dukungan lembaga non-pemerintah dan swasta; (2) pengembangan pemanfaatan ekowisata; dan (3) pengembangan pendidikan lingkungan dan kelautan bagi pelajar, mahasiwa dan masyarakat. Sedangkan ancamannya, adalah: (1) masih adanya aktivitas masyarakat penambang pasir dan terumbu karang; (2) pencemaran yang bersumber dari sampah dan bahan organik; dan (3) kegiatan wisata massal dan belum ramah lingkungan. Unsur-unsur SWOT pengelolaan terumbu karang di Wilayah Utara dirumuskan untuk menyusun strategi pengelolaan terumbu karang yang dibangun dengan menggunakan matriks SWOT (Tabel $3)$.

Berdasarkan Tabel 3 dan Tabel 4, maka nilai IFAS sebesar $1.7188-0.7508=0.9609$, sedangkan nilai EFAS sebesar $1.0469-1.0104=0.0365$. Nilai IFAS positif berarti secara kumulatif faktor kekuatan lebih besar dibandingkan faktor kelemahan, dan nilai EFAS positif berarti secara kumulatif faktor peluang lebih besar dari faktor ancaman (Gambar 4).

\begin{tabular}{|c|c|c|c|c|}
\hline No & Kekuatan & Bobot & Skala & Skor \\
\hline 1 & $\begin{array}{l}\text { Kesadaran masyarakat ter- } \\
\text { hadap perikanan berkelanju- } \\
\text { tan }\end{array}$ & 0,2188 & 3,5000 & 0,7656 \\
\hline 2 & $\begin{array}{l}\text { Dukungan pemerintah yang } \\
\text { kuat }\end{array}$ & 0,0938 & 1,5000 & 0,1406 \\
\hline 3 & Keberadaan regulasi & 0,125 & 2,0000 & 0,2500 \\
\hline \multirow[t]{3}{*}{4} & $\begin{array}{l}\text { Kualitas terumbu karang } \\
\text { sedang }\end{array}$ & 0,1875 & 3,0000 & 0,5625 \\
\hline & Total & & & 1,7188 \\
\hline & Kelemahan & & & \\
\hline 1 & $\begin{array}{l}\text { Lemahnya koordinasi antar } \\
\text { lembaga terkait }\end{array}$ & 0,1406 & 2,2500 & 0,3164 \\
\hline 2 & $\begin{array}{l}\text { Kurangnya pembentukan } \\
\text { kelompok pengelola }\end{array}$ & 0,1094 & 1,7500 & 0,1914 \\
\hline \multirow[t]{3}{*}{3} & Pendanaan terbatas & 0,1250 & 2,0000 & 0,2500 \\
\hline & Total & & & $\mathbf{0 , 7 5 7 8}$ \\
\hline & Peluang & & & \\
\hline 1 & $\begin{array}{l}\text { Adanya dukungan lembaga } \\
\text { non pemerintah dan private }\end{array}$ & 0,1458 & 1,000 & 0,1458 \\
\hline 2 & $\begin{array}{l}\text { Pengembangan pemanfaatan } \\
\text { ekowisata }\end{array}$ & 0,2083 & 2,750 & 0,5729 \\
\hline \multirow[t]{3}{*}{3} & $\begin{array}{l}\text { Pengembangan pendidikan } \\
\text { lingkungan dan kelautan bagi } \\
\text { pelajar, mahasiwa dan } \\
\text { masyarakat }\end{array}$ & 0,1458 & 2,250 & 0,3281 \\
\hline & Total & & & 1,0469 \\
\hline & Ancaman & & & \\
\hline 1 & $\begin{array}{l}\text { Masih adanya aktivitas } \\
\text { masyarakat penambang pasir } \\
\text { dan terumbu karang }\end{array}$ & 0,1875 & 2,2500 & 0,4219 \\
\hline 2 & $\begin{array}{l}\text { Pencemaran yang bersumber } \\
\text { dari sampah dan bahan organik }\end{array}$ & 0,1667 & 2,0000 & 0,3333 \\
\hline \multirow[t]{2}{*}{3} & $\begin{array}{l}\text { Kegiatan wisata yang massal } \\
\text { dan belum ramah lingkungan }\end{array}$ & 0,1458 & 1,7500 & 0,2552 \\
\hline & Total & & & 1,0104 \\
\hline
\end{tabular}

Tabel 3. Nilai unsur SWOT pengelolaan terumbu karang di Wilayah Utara Kepulauan Seribu

Tabel 4. Matrik SWOT Untuk Perumusan Kebijakan Terumbu Karang di Wilayah Utara Kepulauan Seribu

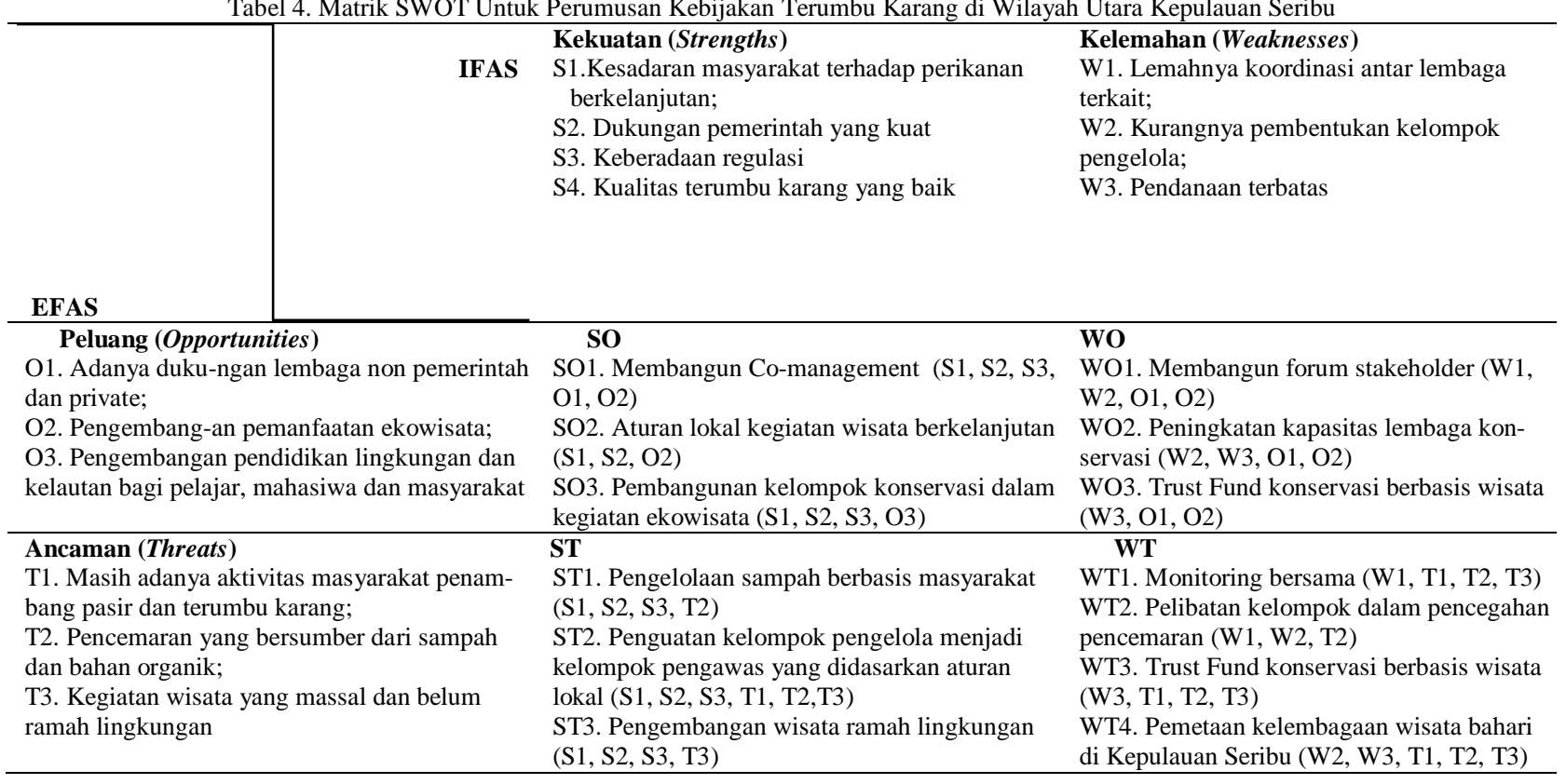




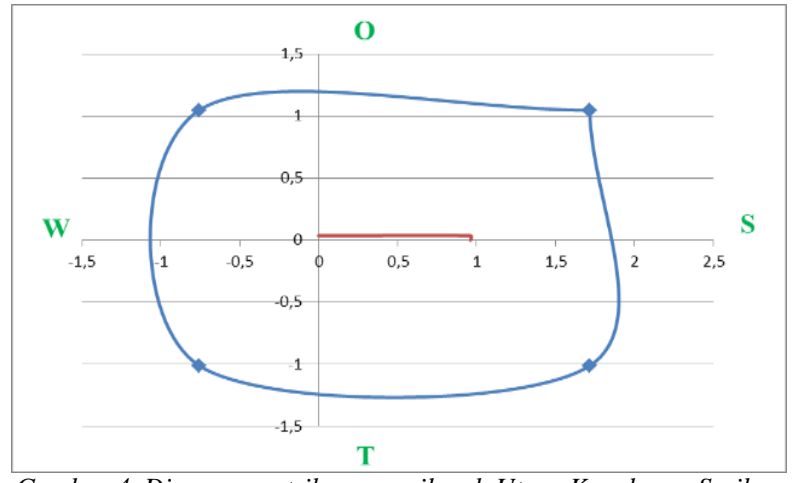

Gambar 4. Diagram matrik space wilayah Utara Kepulauan Seribu

Berdasarkan Gambar 4 dapat dilihat bahwa penge lolaan terumbu karang berada pada kuadran 1 . Artinya, posisi ini menandakan pengelolaan terumbu karang didukung oleh peluang yang ada. Rekomendasi strategi yang diberikan adalah penguatan strategi, artinya pengelolaan terumbu karang dalam kondisi sangat kuat karena didukung oleh peluang yang ada. Oleh karenanya, pengelolaan terumbu karang disarankan untuk memperkuat program yang ada. Oleh karena itu, strategi yang terpilih, adalah: Alternatif A (Membangun Co-management); Alternatif B (Aturan lokal kegiatan wisata berkelanjutan); Alternatif C (Pembentukan kelompok konservasi dalam kegiatan ekowisata).

Berdasarkan hasil analisis tersebut dibuat struktur hierarki seperti Gambar 5. Struktur hierarki tersebut menunjukkan prioritas dari empat alternatif strategi dalam pengelolaan terumbu karang.

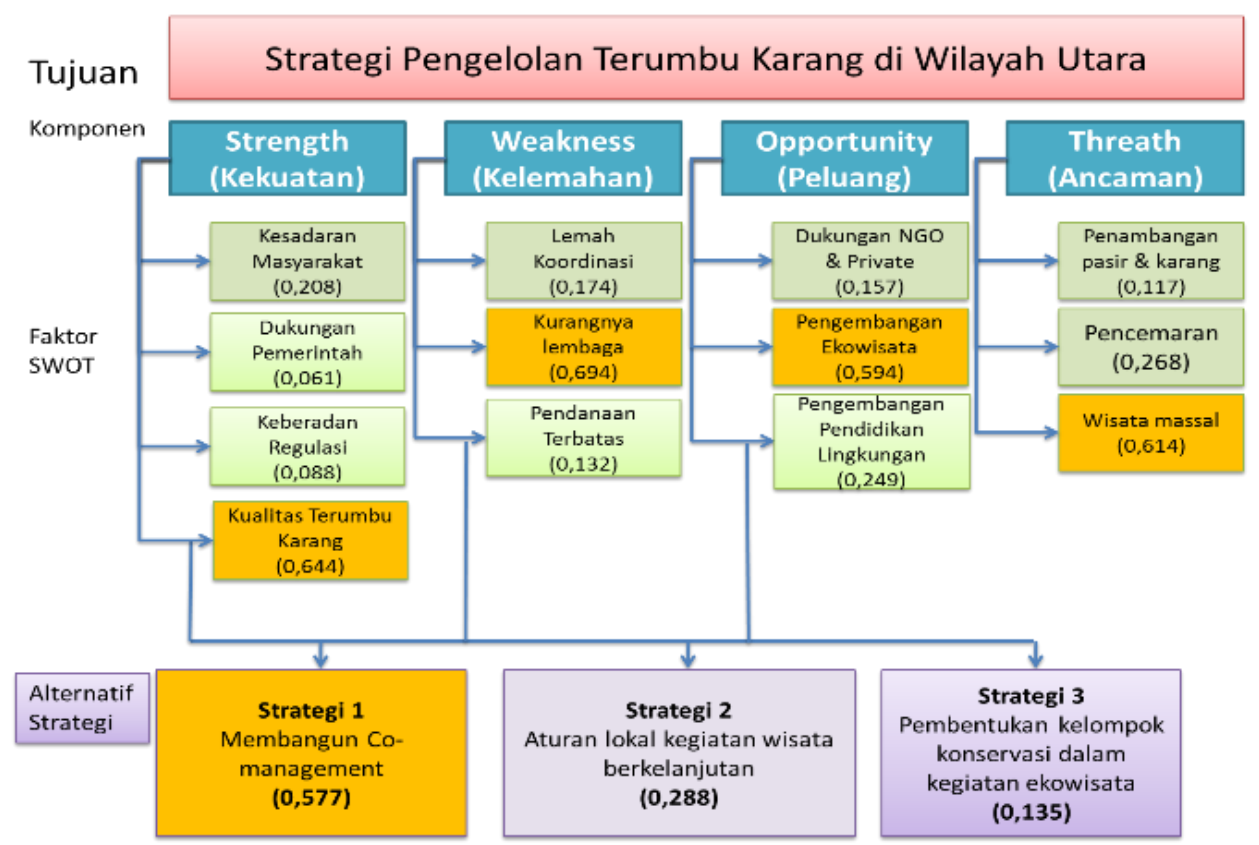

Gambar 5. Struktur hierarki pengembangan pengelolaan terumbu karang di wilayah Utara Kepulauan Seribu

Berdasarkan hasil analisis A'WOT didapatkan prioritas strategi terpilih adalah Membangun Comanagement dengan nilai bobot 57.7\%; Aturan lokal kegiatan wisata berkelanjutan merupakan prioritas kedua dengan nilai $28.8 \%$; dan prioritas ketiga adalah pembentukan kelompok konservasi dalam kegiatan ekowisata dengan nilai bobot 13.5\% (Gambar 6).

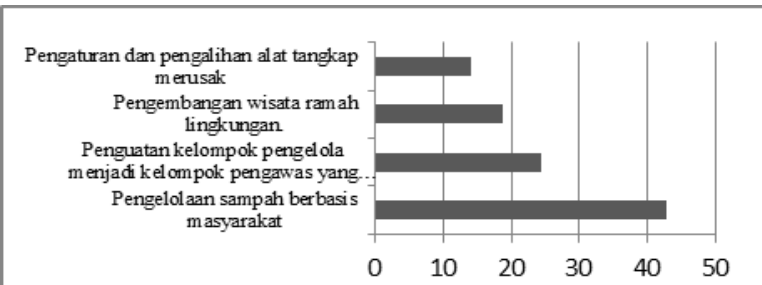

Gambar 6. Strategi prioritas pengelolaan terumbu karang di wilayah Utara Kepulauan Seribu

\subsection{Perbandingan Strategi Pengelolaan Wilayah Utara dan Selatan Kepulauan Seribu}

Hasil analisis kedua wilayah di atas menghasilkan nilai consistency ratio (CR) sebesar 0.03 untuk wilayah Selatan dan 0.04 untuk wilayah Utara. Artinya, data pengisian kuisioner dari responden cukup konsisten sehingga tidak perlu dilakukan revisi pendapat. Revisi pendapat dilakukan apabila nilai CR > 0.1, dengan pengulangan pengisian kuesioner atau melakukan pengolahan data (adjustment) (Saaty, 1983). Strategi pengelolaan untuk wilayah Selatan berada pada kuadran II yang artinya strategi StrengthTreath (ST), sedangkan wilayah Utara berada pada kuadran I yang artinya strategi Strength-Opportunity (SO). Strategi terpilih utama untuk Selatan adalah pengelolaan sampah berbasis masyarakat, sedangkan strategi terpilih utama untuk Utara adalah membangun Co-management. Program dan para pemangku kepent- 
ingan yang terlibat dalam pelaksanaan strategi yang terpilih disajikan pada Tabel 5.

Tabel 5. Matrik Perbandingan Strategi

\begin{tabular}{|c|c|c|c|c|c|}
\hline \multirow{2}{*}{ No } & \multirow{2}{*}{ Wilayah } & \multicolumn{4}{|c|}{ Strategi } \\
\hline & & Kua-dran & Keterangan & Terpilih & Nilai \\
\hline \multirow[t]{4}{*}{1} & \multirow[t]{4}{*}{ Selatan } & \multirow[t]{4}{*}{ II (ST) } & \multirow{4}{*}{$\begin{array}{l}\text { - Menggunakan kekuatan yang ada } \\
\text { untuk mengatasi ancaman. } \\
\text { - Menggunakan kekuatan internal } \\
\text { untuk menghindari atau } \\
\text { mengurangi ancaman eksternal }\end{array}$} & Pengelolaan sampah berbasis masyarakat & $45,1 \%$ \\
\hline & & & & $\begin{array}{l}\text { Pengaturan dan pe-ngalihan alat tangkap } \\
\text { merusak }\end{array}$ & $19,6 \%$ \\
\hline & & & & $\begin{array}{l}\text { Penguatan kelompok pengelola menjadi ke- } \\
\text { lompok pengawas yang didasarkan aturan lokal }\end{array}$ & $17,8 \%$ \\
\hline & & & & Pengembangan wisata ramah lingkungan & $17,4 \%$ \\
\hline \multirow[t]{3}{*}{2} & \multirow[t]{3}{*}{ Utara } & \multirow[t]{3}{*}{$\mathrm{I}(\mathrm{SO})$} & \multirow{3}{*}{$\begin{array}{l}\text { - Memanfaatkan seluruh kekuatan } \\
\text { untuk merebut dan memanfaatkan } \\
\text { peluang sebesar-besarnya. } \\
\text { - Menggunakan kekuatan internal } \\
\text { untuk memanfaatkan peluang } \\
\text { eksternal }\end{array}$} & Membangun Co-management & $57,7 \%$ \\
\hline & & & & Aturan lokal kegiatan wisata berkelanjutan & $28,8 \%$ \\
\hline & & & & $\begin{array}{l}\text { Pembentukan kelompok konservasi dalam } \\
\text { kegiatan ekowisata }\end{array}$ & $13,5 \%$ \\
\hline
\end{tabular}

\section{Kesimpulan}

Isu dan permasalahan pengelolaan terumbu karang di Kepulauan Seribu berbeda-beda antar masingmasing wilayah, seperti di wilayah Selatan yang berdekatan dengan daratan utama DKI Jakarta. Isu permasalahannya meliputi lemahnya kesadaran masyarakat, lemahnya koordinasi, adanya dukungan NGO dan Private, serta tingginya pencemaran. Sementara di wilayah Utara meliputi: kualitas terumbu karang yang masih lebih baik, belum optimalnya lembaga pengelola terumbu karang, pengembangan ekowisata, masih adanya penambangan pasir dan karang, serta ancaman wisata massal.

Strategi untuk wilayah Selatan berada pada kuadran II yang artinya strategi Strength-Treath (ST), sedangkan wilayah Utara berada pada kuadran I yang artinya strategi Strength-Opportunity (SO). Oleh karena itu strategi pengelolaan wilayah Selatan dan Utara berbeda dimana strategi terpilih utama untuk Selatan adalah pengelolaan sampah berbasis masyarakat dan strategi terpilih utama untuk Utara adalah membangun Co-management.

\section{Daftar Pustaka}

[1] Bengen, D.G. dan R. Alex, 2006. Menguak Realitas dan Urgensi Pengelolaan Berbasis Eko-sosio Sistem Pulau-Pulau Kecil. Pusat Pembelajaran dan Pengembangan Pesisir dan Laut, Bogor.

[2] Cleary et al., 2014. Coral reefs next to a major conurbation: a study of temporal change (1985-2011) in coral cover and composition in the reefs of Jakarta, Indonesia. Marine Ecology Progress Series. 50, pp. 89-98.
[3] Faizal, I., dan D. Iriana, 2014. Kondisi dan Distribusi Terumbu Karang pada Zonasi Taman Nasional Kepulauan Seribu, Provinsi DKI Jakarta. Fakultas Perikanan dan Ilmu Kelautan, UNPAD, Bandung, 1-20.

[4] Haruddin A., P. Edi, Sri Budiastuti, 2011. Dampak Kerusakan Ekosistem Terumbu Karang Terhadap Hasil Penangkapan Ikan oleh Nelayan secara Tradisional di Pulau Siompu, Kabupaten Buton, Provinsi Sulawesi Tenggara. Jurnal Ekosains. 3(3), pp. 29-41.

[5] Kangas J., P. Mauno, K. Mikko, K. Miika, 1998. A'WOT: Integrating The AHP With SWOT Analysis. Proceedings 6th ISAHP 2001 Berne, Switzerland. pp. 189-198.

[6] Kusmayadi, Endar S., 2000. Metodologi Penelitian dalam Bidang Kepariwisataan. Jakarta, Gramedia Pustaka Utama.

[7] Mulyana, D., 2001. Metodologi Penelitian Kualitatif: Paradigma Baru Ilmu Komunikasi dan Ilmu Sosial Lainnya. Bandung, Remaja Rosdakarya.

[8] Nasir, M., 1988. Metode Penelitian. Jakarta, Ghalia Indonesia.

[9] Robinson P., 1997. Manajemen Strategis. Jakarta, Binarupa Aksara.

[10] Ruswahyuni, W.P. Pujiono, 2009. Kondisi Terumbu Karang Di Kepulauan Seribu Dalam Kaitan Dengan Gradasi Kualitas Perairan. Jurnal Ilmiah Perikanan dan Kelautan. 1(1), pp. 93101.

[11] Saaty, T.L., 1993. Pengambilan Keputusan Bagi Para Pemimpin. Jakarta, PT. Pustaka Binaman Pressindo.

[12] Santoso, A.D., 2010. Kondisi Terumbu Karang di Pulau Karang Congkak Kepulauan Seribu. Jurnal Hidrosfir Indonesia. 5(2), pp. 73-78.

[13] Sitorus, M.T.F., 1998. Penelitian Kualitatif Suatu Perkenalan. Bogor, Kelompok Dokumentasi Ilmu Sosial.

[14] Suku Dinas Kelautan dan Pertanian Provinsi DKI Jakarta, 2009. DKI Jakarta Tahun 2004-2009. DKI Jakarta, Dinas Kelautan dan Pertanian Provinsi DKI Jakarta.

[15] Widiarti, R., K.P. Ramadhan, 2015. Dinoflagellata Toksik Penyebab Ciguatera Fish Poisoning Di Perairan Pulau Tidung, Kepulauan Seribu. BioWallacea Jurnal Ilmiah Ilmu Biologi. 1(1), pp. 5-8. 